$\begin{array}{ll}\text { Volume } & : \mathbf{7} \\ \text { Nomor } & : \mathbf{3} \\ \text { Bulan } & : \text { Agustus } \\ \text { Tahun } & : \mathbf{2 0 2 1}\end{array}$

\title{
Eksplorasi Pembelajaran Matematika Berbasis Proyek Berbantu E-Modul Ditinjau dari Berpikir Kreatif Siswa
}

\author{
Siti Rodi'ah \\ Isatul Hasanah \\ Institut Agama Islam Negeri Tulungagung \\ Pos-el: hasanahisatul@gmail.com
}

DOI: $10.32884 /$ ideas.v7i3.465

\begin{abstract}
Abstrak
Bahan ajar elektronik yang berorientasi pada aktivitas penemuan dengan diberikan alur kegiatan belajar yang sistematis dan mudah dipahami oleh siswa dapat memudahkan siswa mengeksplorasi kemampuan berpikir kreatifnya. Tujuan penelitian ini adalah mendeskripsikan eksplorasi penggunaan e-modul matematika berbasis proyek ditinjau dari berpikir kreatif siswa. Penelitian ini menggunakan metode kualitatif. Berdasarkan analisis data diperoleh hasil penelitian bahwa siswa dapat mengeksplorasi pembelajaran matematika berbasis proyek berbantu e-modul dengan cukup baik yang ditinjau dari berpikir kreatifnya. Dari 25 siswa diperoleh data pencapaian indikator berpikir kreatif yang dicapai oleh siswa antara lain: kepekaan ada 11 siswa, kelancaran ada 3 siswa, keaslian 8 siswa, dan elaborasi 1 siswa, sedangkan 2 siswa tidak mencapai indikator berpikir kreatif dikarenakan tidak mengikuti pembelajaran matematika berbasis proyek berbantu $e$-modul.
\end{abstract}

\section{Kata Kunci}

Eksplorasi pembelajaran, e-modul, berpikir kreatif

\begin{abstract}
An electronic teacher-oriented invention with a given systematic and easy-to-understand flow oflearning can make it easier for students to explore their creative thinking ability. The purpose of this study is to describe exploration of the use of a project-based mathematical module viewed from student creative thinking. The study involves qualitative methods. Based on data analysis obtained studies that students can explore working -based mathematical learning-module projects quite well covered by creative thinking. From 25 students acquired data of the accomplishment of creative thinking indicators attained by the student are among other things: sensitivity there are 11 students, smoothness there are 3 students, authenticity 8 students, and elaboration 1 student, while 2 students did not reach the indicators of creative thinking because they did not follow the mathematics based project e-module assist.
\end{abstract}

Keyword

Learning Exploration, E-Module, Creative Thingking

\section{Pendahuluan}

Matematika merupakan salah satu mata pelajaran wajib untuk semua jenjang sekolah. Termasuk pada jenjang Sekolah Dasar yang telah dikemas secara tematik maupun tidak tematik. Salah satu kontribusi matematika terhadap peserta didik adalah merangsang peningkatan berpikir secara kritis, kreatif, dan logis yang dapat diterapkan dalam kehidupan nyata (Yilmaz, 2020). Peningkatan berpikir tersebut dapat distimulus melalui kegiatan belajar mengajar yang dirancang oleh guru yaitu guru harus berpedoman pada kurikulum 2013 sebagai acuan dalam merancang kegiatan pembelajaran. Hal ini karena pembelajaran merupakan bentuk implementasi dari kurikulum (Yani, 2014).

Keterampilan berpikir yang harus dikembangkan sesuai Kurikulum 2013 oleh peserta didik adalah kemampuan berpikir kreatif. Septi dkk., memaparkan bahwa keterampilan berpikir kreatif merupakan salah satu keterampilan yang harus dikembangkan kepada peserta didik agar tidak hanya menjadi konsumen saja (Septinaningrum, 2019). Artinya, melalui keterampilan berpikir kreatif, peserta didik dapat menciptakan hal baru yang dapat dijadikan solusi dalam memecahkan permasalahan di masa mendatang. Berpikir kreatif adalah kemampuan yang dimiliki oleh seseorang dalam menemukan solusi permasalahan dengan mudah, menemukan

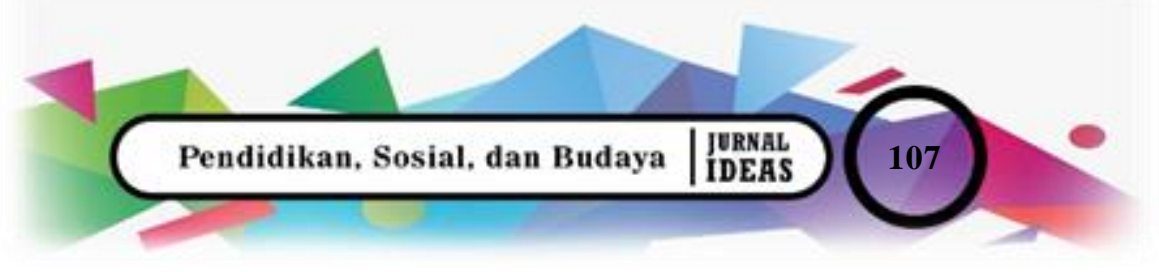




\begin{tabular}{c|ll} 
E-ISSH: 2656-940X & Volume & $: 7$ \\
Pomor & $: 3$ \\
P-ISSH: 2442-367K & Bulan & $:$ Agustus \\
URL:jurnal.ideaspublishing.co.id & Tahun & $: 2021$
\end{tabular}

sistem baru, dan menemukan pemecahan dari suatu soal (Fauzi, 2004) sehingga Kurikulum 2013 dianggap berhasil jika peserta didik memiliki kemampuan berpikir kreatif.

Saat ini, pembelajaran diarahkan pada sistem online. Kegiatan pembelajaran matematika mengarah pada pemanfaatan teknologi sebagai media komunikasi antara peserta didik dengan guru maupun teman sejawat. Akan tetapi, pembelajaran online tanpa adanya inovasi strategi maupun metode pembelajaran tentu tidak akan memberikan pengalaman bermakna bagi peserta didik (Ucu Rosmiati, 2021). Tentu diperlukan eksplorasi pembelajaran matematika yang bermakna untuk memfasilitasi berpikir kreatif peserta didik.

Hasil observasi di lapangan menunjukkan bahwa pembelajaran daring di jenjang Sekolah Dasar belum memberikan pengalaman yang bermakna bagi peserta didik. Guru hanya memberikan materi berupa video pembelajaran atau materi singkat yang dikirimkan melalui WhatsApp. Selanjutnya, peserta didik diarahkan mengerjakan soal-soal latihan di LKS maupun modul. Untuk menyelesaikan soal-soal latihan tersebut, peserta didik diarahkan mencontoh alur penyelesaian yang dipaparkan pada modul. Hal ini men ghambat berpikir kreatif peserta didik.

Solusi dari permasalahan tersebut adalah guru perlu mengeksplorasi pembelajaran matematika yang bermakna. Salah satu metode pembelajaran yang memberikan pengalaman nyata dan sesuai kurikulum 2013 adalah pembelajaran berbasis proyek (project based learning). Melalui metode pembelajaran berbasis proyek peserta didik memperoleh keterampilan dan pengetahuan dengan bekerja dalam jangka waktu yang lama untuk menyelidiki dan menanggapi pertanyaan maupun masalah yang autentik, menarik, dan kompleks (Riley Evans, 2017). Hal ini menjadikan pembelajaran daring lebih menarik dan bermakna bagi peserta didik. Metode berbasis proyek (project based learning) terdiri dari empat tahap utama, yaitu tahap perencanaan, tahap perancangan, tahap pelaksanaan, dan tahap pelaporan (Yanti Rosinda Tinenti, 2018).

Melalui kegiatan pembelajaran berbasis proyek tersebut, peserta didik terdorong untuk menghasilkan karya yang kreatif (Yani, 2014), yaitu melalui penyajian kegiatan pembelajaran yang dilakukan secara kontekstual atau nyata. Pembelajaran kontekstual merupakan pembelajaran yang mengaitkan materi matematika dengan kehidupan nyata (Sri Hartini \& Ramlah, 2021). Hal ini memberikan kemudahan kepada siswa untuk menghubungkan materi matematika dengan kehidupan nyata sehingga peserta didik mampu membuat hubunganhubungan yang baru (Sutarto Hadi, 2017). Aktivitas belajar tersebut dapat mendorong peserta didik untuk berpikir kreatif ditandai dengan menemukan hubungan yang baru.

Penelitian terdahulu memaparkan bahwa ada perbedaan yang signifikan antara kelas eksperimen yang menggunakan model pembelajaran project based learning dan kelas kontrol yang menggunakan model pembelajaran konvensional terhadap kemampuan berpikir kreatif matematika siswa (I Wayan Widana, 2021). Hal ini sejalan dengan temuan penelitian Eka bahwa pembelajaran matematika menggunakan model project based learning menghasilkan produk berupa jejaitan yang pengerjaannya membutuhkan konsep-konsep matematika (I Wayan Eka Mahendra., 2016). Menciptakan produk merupakan implementasi dari keterampilan berpikir kreatif. Dalam matematika, kreativitas atau berpikir kreatif merupakan pemikiran asli dan reflektif serta menghasilkan produk yang kompleks (Siswono, 2011).

Penelitian terdahulu dalam kajian literatur menyebutkan bahwa salah satu komponen pembelajaran berbasis proyek adalah inkuiri atau penemuan di mana melalui inkuiri tersebut berdasarkan temuan peneliti terdahulu bahwa peserta didik aktif bekerja sendiri dalam menemukan ide-ide maupun pemikiran yang baru sehingga dapat meningkatkan kemampuan berpikir kreatif dalam pembelajaran matematika (Nelpita Ulandari, Rahmi Putri, Febria Ningsih, 2019). Melalui kegiatan penyelidikan yang kooperatif dan berkelanjutan (Warsono, 2014) sehingga berdasarkan temuan Lynn dan Hwang pembelajaran berbasis proyek berpuncak pada produk atau presentasi secara realistis (Vicki Lynn Holmes \&Yooyeun Hwang, 2018).

Pembelajaran online saat ini perlu ditetapkan tujuan pembelajaran, model pembelajaran, serta media pembelajaran yang digunakan untuk menyampaikan bahan ajar (Yusfita Yusuf, 2021). Oleh karena itu, penggunaan metode pembelajaran berbasis proyek dengan bantuan bahan ajar yang tepat dapat mendorong berpikir kreatif peserta didik sebagai tujuan pembelajaran matematika.

Berdasarkan temuan di lapangan terjadi berbagai kendala pada pembelajaran online sehingga penelitian ini menggunakan e-modul yang dapat di-download secara online melalui WhatsApp karena mayoritas pembelajaran online pada jenjang sekolah dasar menggunakan aplikasi WhatsApp. E-modul tersebut berisi keseluruhan materi pembelajaran dari suatu unit kompetensi ataupun subkompetensi yang dipelajari (Arsanti, 2018), sedangkan model pembelajaran yang digunakan pada $e$-modul tersebut adalah project based learning. Salah satu komponen 


$\begin{array}{ll}\text { Volume } & : 7 \\ \text { Nomor } & : 3 \\ \text { Bulan } & : \text { Agustus } \\ \text { Tahun } & : 2021\end{array}$

dari $e$-modul adalah aktivitas proyek untuk mendorong peserta didik berpikir kreatif. Aktivitas proyek yang digunakan pada penelitian ini berupa langkah-langkah sintaks yang harus dilakukan oleh peserta didik untuk menemukan suatu konsep matematika sehingga pembelajaran matematika berbasis proyek dengan bantuan $e-m o d u l$ dapat mendorong berpikir kreatif peserta didik.

\section{Metode}

Penelitian ini merupakan penelitian deskriptif kualitatif. Tujuan dari menggunakan jenis penelitian tersebut adalah untuk mengetahui gambaran terkait ekplorasi pembelajaran matematika berbasis proyek berbantu e-modul ditinjau dari berpikir kreatif siswa. Sumber data dalam penelitian ini berupa kata-kata dan tindakan yang didukung dengan adanya dokumentasi atau foto, serta hasil wawancara yang dilakukan oleh peneliti. Data yang diperoleh peneliti berupa data tertulis maupun data statistik. Sumber data yang diambil dalam penelitian ini sebanyak 25 siswa di MI PSM Ngantru. Adapun teknik pengambilan data menggunakan observasi, wawancara, validitas data, dan instrument penelitian. Instrumen yang digunakan oleh peneliti adalah menggunakan tes berupa soal uraian, sedangkan teknik analisis data dalam penelitian ini peneliti menggunakan reduksi data dan sajian data.

\section{Hasil dan Pembahasan \\ Hasil}

Hasil penelitian ini menunjukkan pada implementasi pembelajaran matematika berbasis proyek berbantuan e-modul dapat memfasilitasi berpikir kreatif peserta didik. Yaitu melalui tugas proyek yang dikerjakan secara individu. Di mana peserta didik mengerjakan tugas proyek berdasarkan langkah-langkah sintaks yang sudah diuraikan pada e-modul. Berikut ini hasil pengerjaan tugas proyek dari peserta didik sesuai yang ditampilkan pada $e$-modul.

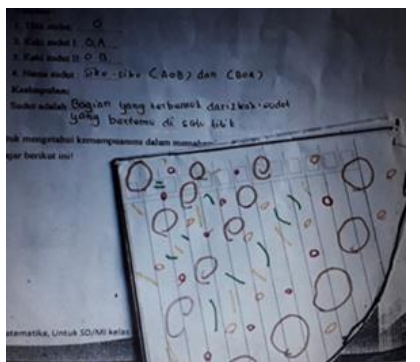

Gambar 1 Hasil Pekerjaan Aktivitas Proyek Siswa 1

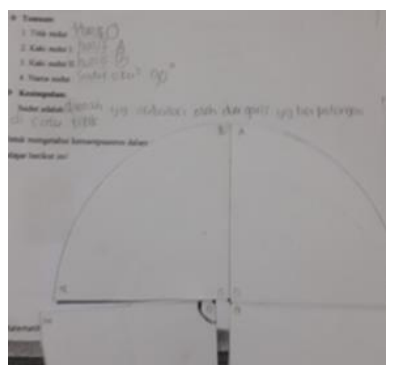

Gambar 2 Hasil Pekerjaan Aktivitas Proyek Siswa 2

Kedua gambar tersebut merupakan hasil pekerjaan peserta didik yang dituliskan pada lembaran yang diberikan oleh peneliti terkait hasil temuan yang diperolehnya dari aktivitas proyek. Terlihat masing-masing peserta didik mendefinisikan sudut dengan cara yang berbeda. Mereka menjawab berdasarkan aktivitas proyek dan pemikiran kreatifnya. Di mana gambar 1 menunjukkan indikator berpikir kreatif pada aspek kepekaan. Yaitu mampu mendeteksi suatu pernyataan dalam permasalahan. Gambar 1 menunjukkan bahwa siswa mampu membuat potongan pizza sesuai petunjuk aktivitas proyek yang diuraikan di dalam e-modul. Dan mendefinisikan sudut adalah bagian yang terbentuk dari dua kaki sudut yang bertemu di satu titik. Hal ini didasarkan pada aktivitas proyek yang telah dilakukan oleh siswa, sedangkan gambar 2 menunjukkan indikator berpikir kreatif pada aspek kelancaran, yaitu kemampuan siswa memperoleh berbagai gagasan sehingga menghasilkan ide yang bervariasi. Di mana, ide dari gambar 2 berbeda dari mayoritas teman sekelasnya. Baik dari pembuatan potongan pizza maupun mendefinisikan sudut.

Berdasarkan hasil analisis peneliti terhadap berpikir kreatif siswa terhadap aktivitas proyek yang dilakukan, maka dapat ditunjukkan pada diagram 1 berikut ini. 


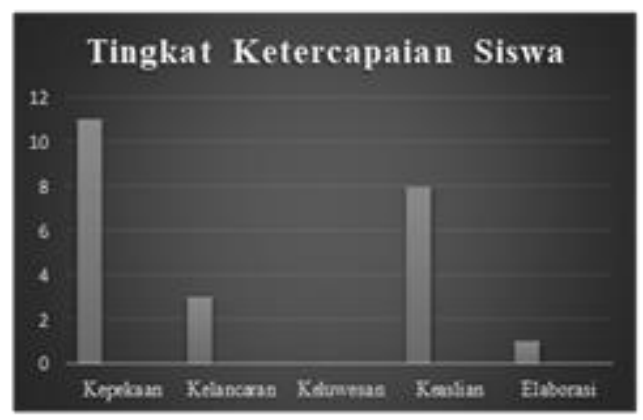

Diagram 1 Tingkat Ketercapaian Siswa

Berdasarkan diagram 1 bahwa aktivitas proyek di dalam $e$-modul belum mendorong berpikir kreatif sis wa pada indikator keluwesan. Hal ini dikarenakan kedua indikator tersebut mengarah pada berbagai gagasan atau ide. Yaitu memberikan jawaban yang benar lebih dari satu. Sedangkan aktivitas proyek tersebut mengarah pada definisi yang cukup diuraikan pada satu jawaban yang benar.

Hasil dokumentasi peneliti terhadap pekerjaan siswa pada e-modul bahwa tidak semua peserta didik mengikuti pembelajaran sesuai alur yang telah diuraikan di dalam e-modul. Berdasarkan data yang diperoleh peneliti, bahwa dari 25 objek penelitian ada 9 peserta didik yang hanya mengisi hasil temuan tanpa mengikuti aktivitas proyek sesuai alur yang disajikan pada $e$-modul, terutama aktivitas proyek yang sudah disajikan pada $e$ modul. Ada dua orang siswa yang tidak mengerjakan aktivitas proyek, baik mengisi hasil temuan maupun mambuat produk. Data yang diperoleh peneliti berasal dari dokumentasi yang dikirimkan oleh peserta didik di grub WhatsApp. Berikut ini adalah hasil pekerjaan siswa yang hanya mengisi hasil temuan tanpa mengikuti aktivitas proyek sesuai alur di dalam e-modul.

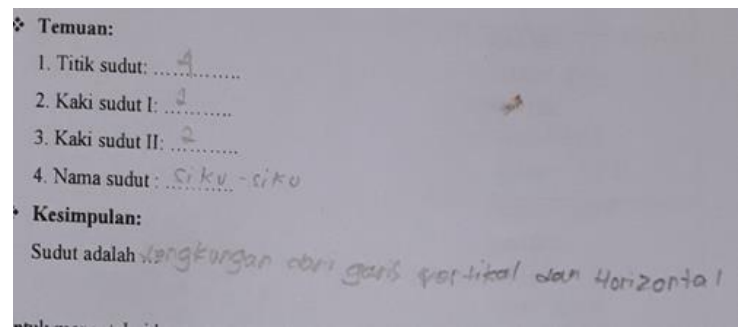

Gambar 3 Hasil PekerjaanAktivitas Proy ek Siswa 3

Gambar 3 menunjukkan definisi sudut yang kurang tepat. Tetapi, pada indikator berpikir kreatif termasuk keaslian yang berbeda dari yang lain. Gambar 1, 2, dan 3 merupakan hasil eksplorasi siswa berdasarkan berpikir kreatifnya. Baik dari cara menghasilkan karya berupa potongan pizza maupun mendefinisikan sudut. Akan tetapi, hasil temuan siswa berdasarkan aktivitasnya proyeknya masih kurang tepat. Pada gambar 1 belum benar dalam menyebutkan nama sudut. Seharusnya, siswa memberikan jawaban sudut AOB atau BOA. Gambar 2 menunjukkan jawaban yang salah saat mengisi hasil temuan berdasarkan aktivitas proyeknya. Yaitu pada pemberian nama kaki sudut dan nama sudut. Gambar 2 menyebutkan nama kaki sudut, seperti titik sudut, yaitu satu huruf capital, sedangkan gambar 3 semua jawaban masih kurang tepat baik hasil temuan maupun menjelaskan definisi sudut karena siswa pada gambar 3 tidak mengerjakan aktivitas proyek sesuai langkahlangkah yang telah diuraikan di dalam e-modul.

E-modul telah disusun berdasarkan alur pembelajaran berbasis proyek di mana sebelum aktivitas proyek, siswa diberikan permasalahan kontekstual beserta gambar konkrit yang disesuaikan dengan konten yang akan dipelajari. Selain itu, di dalam e-modul diuraikan alat dan bahan yang harus dipersiapkan oleh siswa untuk mengerjakan aktivitas proyek, sedangkan aktivitas proyek telah disusun secara rinci untuk memandu siswa mengkontruksi pengetahuan secara mandiri. Akan tetapi, berdasarkan gambar 1, 2, dan 3 siswa masih belum memahami aktivitas proyek yang telah dilakukannya. Hal ini sesuai jawaban siswa pada hasil temuan dari aktivitas proyek yang telah dilakukan. Di mana hasil temuan tersebut masih kurang tepat.

Berdasarkan hasil penelitian dan temuan peneliti terhadap pembelajaran matematika berbasis proyek berbantu e-modul bahwa siswa dapat mengeksplorasi e-modul tersebut ditinjau dari berpikir kreatif, yaitu melalui pembuatan produk berupa potongan pizza dan mendefinisikan sudut. Di mana aktivitas proyek tersebut 


$\begin{array}{ll}\text { Volume } & : 7 \\ \text { Nomor } & : \mathbf{3} \\ \text { Bulan } & : \text { Agustus } \\ \text { Tahun } & : \mathbf{2 0 2 1}\end{array}$

menampilkan ide atau gagasan yang berbeda-beda walaupun siswa belum sepenuhnya memahami aktivitas proyek yang telah dikerjakan sebagaimana penjelas an di atas, yaitu berdasarkan gambar 1, 2, dan 3.

\section{Pembahasan}

Berdasarkan hasil analisis data menunjukkan penerapan pembelajaran matematika berasis proyek berbantu $e$ modul di masa pandemi covid-19 dapat terlaksana cukup baik. Studi Indra dan kawan-kawan bahwa model pembelajaran berbasis proyek (project based learning) dapat menunjang pembelajaran jarak jauh saat pandemi covid-19 dengan berbantu e-modul (Indra Kurniawan Rezki, Joni Karnando, 2021). Hal ini dikarenakan $e$-modul yang dirancang oleh peneliti sesuai dengan langkah-langkah pembelajaran berbasis proyek, yaitu perencanaan, perancangan, pelaksanaan, dan pelaporan. Secara rincinya, peneliti mengambil kajian teori dari penelitian terdahulu yaitu: (1) memulai pertanyaan yang essensial; (2) membuat langkah-langkah pengerjaan tugas proyek; (3) me-monitoring perkembangan tugas proyek peserta didik.; (4) menilai tugas proyek peserta didik dengan menyediakan assessment penilaian; (5) memberikan evaluasi terhadap peserta didik (Meti Sopiani, Tatang Syaripudin, 2019).

Pembelajaran matematika berbasis proyek berbantu e-modul dapat memfasilitasi siswa berpikir kreatif, yaitu sejalan dengan hasil penelitian terdahulu bahwa model pembelajaran project based learning dapat memengaruhi berpikir kreatif siswa melalui aktivitas memberikan gagasan dan mengerjakan tugas pada LKS secara berkelompok sehingga peserta didik saling mengoreksi ketika presentasi berlangsung (Kuo-Hung Tseng, Chi-Cheng Chang, Shi-Jer Lou, 2016). Hal ini diperkuat oleh studi Roazah bahwa perkembangan kemampuan berpikir kreatif peserta didik dimulai dari aktivitas berpikir konkrit menuju berpikir abstrak (Siti Roazah, 2020), sedangkan aktivitas belajar berbasis tugas proyek berakar dari tradisi pragmatis John Dewey adalah learning by doing (Warsono, 2014) sehingga berdasarkan hasil penelitian ini diperoleh diagram ketercapaian peserta didik yang mampu mencapai tiga indikator berpikir kreatif.

Indikator berpikir kreatif yang dapat dicapai oleh siswa kelas IV MI PSM Ngantru adalah kepekaan, keaslian dan elaborasi. Menurut Yuliana bahwa indikator berpikir kreatif terdiri dari lima aspek, yaitu kepekaan, kelancaran, keluwesan, keaslian, dan elaborasi (Yuliana Eli, 2021). Kepekaan merupakan kemampuan siswa mendeteksi suatu pernyataan dalam permasalahan. Pada aspek kepekaan berkembang dengan baik yang ditunjukkan pada diagram ketercapaian berpikir kreatif siswa. Di dalam e-modul berbasis tugas proyek, peserta didik diberikan permasalahan yang essensial berupa bagian potongan pizza yang membentuk sudut. Melalui permasalahan essensial tersebut siswa mampu menghubungkan aktivitas proyek dengan makna dan definisi sudut.

Aspek selanjutnya adalah kelancaran yang merupakan kemampuan siswa untuk menghasilkan berbagai gagasan sehingga menghasilkan sebuah ide yang bervariasi (Supardi U. S., 2016). Melalui langkah-langkah aktivitas proyek, siswa dapat membuat berbagai cara menghasilkan produk yang telah diperintahkan dan menemukan definisi sudut yang berbeda dari teman sebayanya.

Aspek ketiga adalah keluwesan yang merupakan kemampuan siswa menghasilkan banyak gagasan (Amidi, 2016). Pada aspek tersebut, kemampuan siswa belum tampak terhadap eksplorasi pembelajaran matematika berbasis tugas proyek berbantu $e$-modul ditinjau dari berpikir kreatifnya.

Aspek keempat adalah keaslian yang merupakan kemampuan siswa mengemukakan gagasan yang tidak lazim. Melalui aktivitas dan hasil temuannya, siswa dapat mengeksplorasi berpikir kreatifnya pada aspek keaslian.

Aspek yang terakhir adalah elaborasi. Merupakan kemampuan siswa menambah situasi permasalahan agar menjadi lengkap, seperti menambahkan table, grafik, gambar, model, dan kata-kata yang berguna untuk mengembangkan ide hasil karya (Yuliana Eli, 2021). Melalui aktivitas proyek, siswa dapat menambahkan katakata maupun simbol yang memudahkannya untuk mengembangkan ide. Pada aspek ini, hanya satu siswa yang dapat mencapai indikator berpikir kreatif tersebut.

Berdasarkan hasil penelitian dan kajian teori berpikir kreatif, maka siswa dapat mengeksplorasi pembelajaran matematika berbasis tugas proyek berbantu e-modul ditinjau dari berpikir kreatifnya. Hal ini sejalan dengan studi Gadis, Mustaji, dan Bachtiar bahwa adanya pengaruh yang signifikan antara kelas eksperimen dan kelas kontrol terhadap peningkatan berpkir kreatif siswa dalam pembelajaran project based learning secara online (Gadis Hayuhana Siskawati, Mustaji, 2020). Penelitian terdahulu memaparkan bahwa

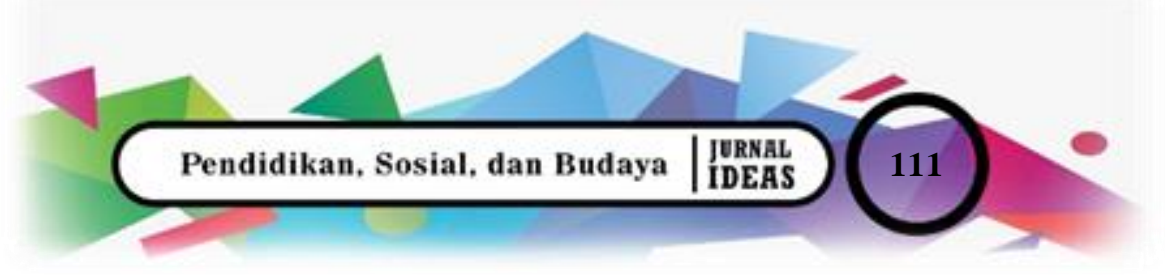




\begin{tabular}{c|ll} 
E-ISSH: 2656-940X & Volume & $: 7$ \\
Pomor & $: 3$ \\
P-ISSH: 2442-367K & Bulan & $:$ Agustus \\
URL:jurnal.ideaspublishing.co.id & Tahun & $: 2021$
\end{tabular}

pembelajaran yang berkaitan dengan pembuatan proyek dapat menjadikan peserta didik lebih memahami konsep materi dan berpikir kreatifnya akan meningkat (Astri May Handayani, Uki Suhendar, 2021). Akan tetapi, pada penelitian ini ada suatu permasalahan yaitu siswa belum optimal dalam menemukan pengetahuan yang benar. Hal ini berdasarkan hasil penelitian yang ditunjukkan oleh gambar 1, 2, dan 3. Hasil penelitian terdahulu menyebutkan bahwa pembelajaran berbasis proyek tidak berjalan dengan baik pada pelajaran matematika dikarenakan sulitnya materi untuk dipelajari (Kuo-Hung Tseng, Chi-Cheng Chang, Shi-Jer Lou, 2016). Itu karena pembelajaran berbasis proyek dapat bekerja dengan baik kepada siswa yang sudah memiliki pengetahuan konseptual yang mendalam tentang materi pelajaran, tetapi mungkin merugikan bagi mereka yang hanya memiliki pengetahuan yang dangkal tentang materi tersebut (Vicki Lynn Holmes \&Yooyeun Hwang, 2018).

Berdasarkan data yang diperoleh peneliti bahwa sembilan siswa tidak mengerjakan aktivitas proyek sesuai alur yang diuraikan di dalam $e$-modul dan ada dua siswa yang tidak mengerjakan $e$-modul sama sekali. Akan tetapi, studi Hanifa, Mujib dan Rizki menyatakan bahwa penggunaan e-modul dapat mengefektifkan model pembelajaran (Hanifa Ainun Nisa, Mujib, 2020) . E-modul yang disusun oleh peneliti berupa konsep belajar secara individu. Padahal pembelajaran berbasis proyek menurut Vicky \& Yooyeun adalah pembelajaran yang memungkinkan peserta didik dapat belajar secara kolaboratif untuk merancang solusi, pertanyaan dan masalah yang autentik dan bermakna di dunia nyata (Vicki Lynn Holmes \&Yooyeun Hwang, 2018). Belajar secara kolaboratif menjadikan siswa lebih termotivasi untuk mencari dan menemukan jawaban dari masalah-masalah menghitung luas bangun datar. Melalui belajar secara kelompok, siswa memiliki rasa permasalahan yang sama dalam pengerjaan proyek sehingga mereka saling mengoreksi ketika presentasi berlangsung (Husnul Khotimah, Suhirman, 2020).

Selain ditinjau dari aspek e-modul matematika, tentu peran guru sangat essensial dalam membimbing peserta didik melaksanakan aktivitas proyek secara tepat, menemukan pengetahuan secara mandiri dengan benar sehingga siswa mampu mengeksplorasi kemampuan berpikir kreatifnya secara tepat. Hal ini berdasarkan studi terdahulu bahwa guru dapat memberikan kemudahan pada pembelajaran berbasis proyek dengan memberikan siswa kesempatan untuk menerapkan ide siswa sendiri dan membelajarkan siswa secara sadar dalam menggunakan strategi mereka sendiri untuk belajar (Indri Octaviyani, Yaya Sukjaya Kusumah, 2020).

\section{Simpulan}

Berdasarkan analisis data yang telah diuraikan di atas, peneliti menyimpulkan:

1. Siswa dapat mengeksplorasi pembelajaran matematika berbasis proyek berbantu e-modul dengan cukup baik yang ditinjau dari berpikir kreatifnya. Indikator pencapaian berpikir kreatif yang dicapai oleh siswa antara lain: kepekaan ada 11 siswa, kelancaran ada 3 siswa, keaslian 8 siswa, dan elaborasi 1 siswa. Pencapaian indikator tersebut dinilai dari hasil kerja proyek berupa potongan pizza dan mendefinisikan sudut sesuai bahasanya sendiri di mana masing-masing siswa memberikan ide maupun gagasan sesuai kemampuannya sendiri.

2. Siswa masih kesulitan dalam mengontruksi pengetahuannya secara benar melalui pembelajaran matematika berbasis proyek berbantu $e$-modul yang didesain belajar individu.

3. Penyajian alur sintaks aktivitas proyek di dalam $e$-modul yang disesuaikan tingkat perkembangan kognitif siswa sangat mendukung eksplorasi berpikir kreatifnya. Selain itu, desain belajar secara kolaboratif dengan bimbingan guru dapat member motivasi dan kemudahan siswa untuk mengeksplorasi berpikir kreatifnya dengan tepat.

Berdasarkan temuan dan hasil dari penelitian ini, maka peneliti merekomendasikan penerapan pembelajaran matematika berbasis proyek berbantu e-modul pada siswa kelas IV SD untuk mengeksplorasikan kemampuan berpikir kreatifnya. Salah satu pembelajaran yang menekankan pada aktivitas siswa secara aktif untuk mengkonstruksi pengetahuan secara mandiri. Melalui e-modul, maka pembelajaran matematika berbasis proyek dapat diterapkan kepada siswa secara online untuk mengeksplorasi kemampuan berpikir kreatifnya.

\section{Daftar Rujukan}

Ahmad Yani. (2014). Mindset Kurikulum 2013. Publisher:Bandung: Alfabeta

Amidi, M. \& Z. Z. (2016). Membangun Kemampuan Berpikir Kreatif Matematis dengan Model Pembelajaran Berbasis Masalah Berbantu E-Learning. Membangun Kemampuan Berpikir Kreatif Matematis dengan Model Pembelajaran Berbasis Masalah Berbantu E-Learning. Universitas Negeri Semarang.

Astri May Handay ani, Uki Suhendar, S. P. M. (2021). Model PJBL dengan Lembar KWL dalam Meningkatkan Kemampuan 


$\begin{array}{ll}\text { Volume } & : 7 \\ \text { Nomor } & : 3 \\ \text { Bulan } & : \text { Agustus } \\ \text { Tahun } & : 2021\end{array}$

Berpikir Kreatif Matematis. Jurnal Pendidikan Matematika (Histogram), 4(2).

Fauzi. (2004). Psikologi Umum. Bandung: Pustaka Setia.

Gadis Hayuhana Siskawati, Mustaji, B. S. B. (2020). Pengaruh Project Based Learning Terhadap Kemampuan Berpikir Kreatif Siswa pada Pembelajaran Online. Jurnal Teknologi Pendidikan dan Pembelajaran, 5(2).

Hanifa Ainun Nisa, Mujib, R. W. Y. P. (2020). Efektivitas E-modul dengan Flip Pdf Professional Berbasis Gamifikasi Terhadap Siswa SMP. Jurnal Pendidikan Matematika Raflesia., 5(2).

Husnul Khotimah, Suhirman, R. (2020). Pengaruh Model Pembelajaran Project Based Learning Terhadap Kreatifitas Berpikir dan Literasi Sains Siswa SM AN 1 Gerung Tahun 2018/2019. Jurnal Kimia dan Pendidikan Kimia, 2(1).

I Wayan Eka Mahendra. (2016). Project Based Learning Bermuatan Etnomatematika Dalam Pembelajaran Matematika. Jurnal Pendidikan Indonesia, 6(1).

I Way an Widana, K. L. S. (2021). I Wayan Widana, Kadek Lisa Septiari. 2021. Kemampuan Berpikir Kreatif dan Hasil Belajar Matematika Siswa Menggunakan Model Pembelajaran Project Based Learning Berbasis Pendekatan STEM. Jurnal Elemen, 7(1). https://doi.org/10.29408/jel.v7i1.3031.

Indra Kurniawan Rezki, Joni Karnando, E. T. (2021). Efektivitas E-modul Berbasis Project Based Learning Selama Pembelajaran Jarak Jauh. Jurnal Vokasi Informatika (JAVIT), 1(1).

Indri Octaviy ani, Yay a Sukjay a Kusumah, A. H. (2020). Peningkatan Kemampuan Berpikir Kreatif Matematis Siswa Melalui Model Project Based Learning dengan Pendekatan STEM. Journal on Mathematics Education Research, 1(1).

Istanti Tri Wulandari. (2020). Pengembangan Buku Panduan Penerapan Model Project Based Learning dalam Meningkatkan Kerjasama Anak Usia 5-6 Tahun. In Tesis.

Kuo-Hung Tseng, Chi-Cheng Chang, Shi-Jer Lou, W.-P. C. (2016). Attitudes Towards Science, Technology, Engineering and Mathematics (STEM) in a Project-Based Learning (PJjBL) Environment. Ediubasic, 23(2). https://doi.org/10.1007/s10798-011-9160-x

Meilan Arsanti. (2018). Pengembangan Bahan Ajar Mata Kuliah Penulisan Kreatif Bermuatan Nilai-Nilai Pendidikan Karakter Religius Bagi Mahasiswa Prodi PBSI, FKIP, UNISSULA. 1(1).

Meti Sopiani, Tatang Syaripudin, A. S. (2019). Penerapan Model Project Based Learning untuk Meningkatkan Ecoliteracy Siswa dalam Mengelola Sampah di Kelas V SD. Jurnal Pendidikan Sekolah Dasar, 4(3).

Nelpita Ulandari, Rahmi Putri, Febria Ningsih, A. P. (2019). Efektifitas Model Pembelajaran Inquiry Terhadap Kemampuan Berpikir Kreatif Siswa pada Materi Teorema Pythagoras. Jurnal Cendekia: Jurnal Pendidikan Matematika, 3(2).

Rezan Yilmaz. (2020). Prospective Mathematics Teachers Cognitive Competences On Realistic Mathematics Education. Journal on Mathematics Education, 11(1).

Riley Evans. (2017). Math Path: Encouraging Female Students in Mathematics Through Project-Based Learning. Problems, Resources, and Issues in Mathematics Undergraduate Studie. 3(3). https://doi.org/10. 1080/1051 1970.2017.1339154

Septinaningrum. (2019). Improving Creative Thinking Ability of Prospective Elementary School Teachers Through ReadAnswer-Discuss-Explain-and Create (RADEC) Project-Oriented Learning Model. ICCE, 2(2).

Siswono. (2011). Level of Student's Creative Thinking in Classroom Mathematics. Educational Research and Review, 6(7).

Siti Roazah. (2020). Pengembangan Lembar Kerja Siswa (LKS) Matematika Berbasis Open-Ended Problem untuk Meningkatkan Berpikir Kreatif Peserta Didik Di SDIT Baitul Qur'an dan MI Diniyah Putri Lampung. Tulungagung: Pascasarjana IAIN Tulungagung.

Sri Hartini \& Ramlah. (2021). Eksplorasi Etnomatematika dalam Kesenian Tari Jaipong Kabupaten Karawang. Jurnal IDEAS, 7(2).

Supardi U. S. (2016). Peran Berpikir Kreatif dalam Proses Pembelajaran Matematika. Jurnal Formatif., 2(3).

Sutarto Hadi. (2017). Pendidikan Matematika Realistik: Teori, Pengembangan, dan Implementasinya. Depok: Rajawali Pers.

Ucu Rosmiati, P. L. (2021). Inovasi Model Pembelajaran PBI (Problem Based Instruction) Berbasis WhatsApp Sebagai Langkah Solutif Pembelajaran di Masa Pandemi Covid-19. Jurnal Nasional Pendidikan Matematika (JNPM), 5(1).

Vicki Lynn Holmes \&Yooyeun Hwang. (2018). Exploring the Effects of Project Based Learning in Secondary Mathematics Education. The Journal of Educational Research., 4(2). https://doi.org/10.1080//00220671. 2014. 979911.

Warsono. (2014). Pembelajaran Aktif. Bandung: Remaja Rosdakarya.

Yanti Rosinda Tinenti. (2018). Model Pembelajaran Berbasis Proyek (PBP) dan Penerapannya dalam Proses Pembelajaran di Kelas. Yogyakarta.: Deepublish.

Yuliana Eli. (2021). Pengembangan Soal Open Ended pada Pembelajaran Matematika Untuk Mengidentifikasi Kemampuan Berpikir Kreatif Siswa. Jurnal Proseding Seminar Nasional Pendidikan Matematika (SNAPTIKA).

Yusfita Yusuf. (2021). .Implementasi E-Learning dengan Model Pace Berbantuan Modul Berbasis Masalah pada Kondisi Pandemi Covid-19. Jurnal Penelitian Matematika dan Pendidikan Matematika., 4(1). 


\begin{tabular}{c|ll} 
De-ISSH: 2656-940K & Volume & $: 7$ \\
Nomor & $: 3$ \\
P-ISSH: 2442-367K & Bulan & $:$ Agustus \\
URL:jurnal.ideaspublishing.co.id & Tahun & $: 2021$
\end{tabular}

